\title{
Sjálfsvígstilraunir meðhöndlaðar á gjörgæsludeildum Landspítala árin 2000-2004
}

\section{Kristinn Örn Sverrisson ${ }^{1,2}$}

í sérnámi í svæfinga- og gjörgæslulæknisfræði

Sigurður Páll

Pálsson ${ }^{3}$ geðlæknir

Kristinn

Sigvaldason ${ }^{1}$

svæfinga- og gjörgæslulæknir

\section{Sigurbergur}

Kárason ${ }^{1,4}$

svæfinga- og gjörgæslulæknir

Lykilorð: sjálfsvígstilraun, sjálfsvíg, lyfjaeitrun, gjörgæsla, geðvernd.

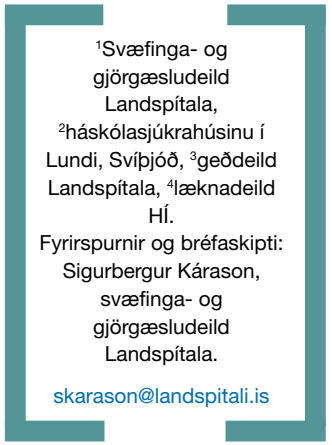

\section{Ágrip}

Tilgangur: Аð kanna afdrif peirra sem parfnast innlagnar á gjörgæslu eftir alvarlega sjálfsvígstilraun.

Aðferðir: Aftursæ rannsókn á innlögnum á gjörgæsludeildir Landspítala vegna alvarlegra sjálfsvígstilrauna árin 2000-2004.

Niðurstöður: Innlagnir vegna alvarlegra sjálfsvígstilrauna voru 251 (4\% allra innlagna, $61 \%$ konur, 39\% karlar, meðalaldur 36 ár \pm 14 ).

Tíu prósent lögðust inn oftar en einu sinni og 61\% höfðu áður gert alvarlega sjálfsvígstilraun. Inntaka lyfja var algengasta aðferðin (91\%) og oftast voru notuð bensódíazepín. Meðferð í öndunarvél purftu 27\% sjúklinga og algengasti fylgikvillinn var lungnabólga. Í kjölfarið voru $36 \%$ sjúklinga lagðir inn á geðdeild en $80 \%$ fengu eftirfylgd innan geðheilbrigðiskerfisins. Algengasta geðgreining var fíkn (43\%). Stór hluti sjúklinga voru fráskildir eða einhleypir og atvinnupátttaka lítil. Prjú prósent sjúklinga lést af völdum alvarlegra sjálfsvígstilrauna og á 3-7 ára eftirfylgdartímabili lést 21 sjúklingur (10\%), flestir fyrir eigin hendi. Í aðhvarfsgreiningu höfðu einungis fjöldi inntekinna taflna, APACHE II gildi og fjöldi sjúkdómsgreininga forspárgildi varðandi horfur sjúklinga.

Ályktun: Petta er ungur sjúklingahópur, meirihluti konur, endurteknar alvarlegar sjálfsvígstilraunir eru algengar, félagslegar aðstæður erfiðar og dánartíðni há prátt fyrir að hátt hlutfall fái eftirfylgd innan geðheilbrigðiskerfisins. Рað vekur spurningar um hvort meðferðarúrræði sem í boði eru séu nægjanlega árangursrík.

\section{Inngangur}

Sjálfsvíg og sjálfsvígshegðun eru talin vera alvarlegt lýðheilsuvandamál um heim allan. ${ }^{1}$ Á Íslandi eru sjálfsvíg í tíunda sæti sem dánarorsök allra aldurshópa ${ }^{2}$ og fjöldi sjálfsvíga er 10-13 tilfelli á hverja 100 púsund íbúa á ári ${ }^{2-6}$ sem er svipað og í Noregi en nokkru lægra en í Danmörku, Svípjóð og Finnlandi, sem hefur haft hæstu tíðni Norðurlandanna. ${ }^{4,5}$ Sjálfsvígstilraunir eru taldar 3-40 sinnum fleiri en sjálfsvíg ${ }^{1,3,7}$ en tilraun til sjálfsvígs er talin vera sá áhættupáttur sem hefur hvað sterkust tengsl við síðara sjálfsvíg. ${ }^{1,8}$ Karlar eru taldir í meiri sjálfsvígsáhættu eftir sjálfsvígstilraun en konur og einnig miðaldra og eldra fólk miðað við yngri einstaklinga. 9, 10

Árlega koma um 500 manns á bráðadeildir Landspítala vegna sjálfsvígstilrauna eða sjálfskaða. ${ }^{11}$ Sjálfsvígstilraun í bókstaflegasta skilningi er verknaður af ásettu ráði par sem einstaklingur hefur ætlað að stytta sér aldur, en markmiðið ekki náðst. Pað geta verið mismunandi ástæður á bak við slíkan verknað, en í öllum tilvikum knýr neyð, uppgjöf, kreppa eða sambærilegt hættuástand fram neyðarkall. Sjálfsvígstilraunum er pví stundum skipt í prjá flokka: a) raunverulegur ásetningur að deyja, b) hróp á hjálp, og c) tilraun til að hafa áhrif á umhverfið eða tilraun til athygli. ${ }^{8,} 12$ Раð ber pó ávallt að taka verknaðinn alvarlega og nýta tækifærið til að beita forvörnum gagnvart síðara sjálfsvígi.

Ekki hefur verið framkvæmd rannsókn áður hér á landi á peim hópi sjúklinga sem gerir alvarlegustu tilraunirnar, lifir af og parfnast innlagnar á gjörgæsludeild. Markmið pessarar rannsóknar var að fá betri upplýsingar um sjúklingahópinn, hvaða meðferð hann hlaut á gjörgæsludeild og hver urðu afdrif einstaklinga innan hans. Að auki var leitað eftir páttum sem mögulega hefðu forspárgildi varðandi lifun peirra.

\section{Efniviður og aðferðir}

Að fengnu leyfi Persónuverndar og Vísindasiðanefndar var farið yfir allar innlagnir á gjörgæsludeildir Landspítala tímabilið 2000-2004 og safnað upplýsingum um alla pá sjúklinga sem lagðir voru inn vegna sjálfsvígstilraunar. Leitað var upplýsinga úr skrám gjörgæsludeilda varðandi aðdraganda og tegund sjálfsvígstilraunar, helstu meðferð og afdrif einstaklinga. Til mats á líkamlegu ástandi sjúklinga við komu var stuðst við APACHE II stigunarkerfi' ${ }^{13}$ (stig gefin fyrir meðvitund, lífsmörk, fyrri sjúkdóma og niðurstöður blóðrannsókna fyrsta sólarhring eftir innlögn). Upplýsingum var einnig safnað úr skrám 
geðdeildar um geðgreiningu, félagslega stöðu, eftirfylgni og afdrif. Gögn frá gjörgæsludeild og geðdeild voru sampætt til að leita að páttum sem gæu haft forspárgildi um horfur sjúklinga. Kannað var í pjóðskrá hvort einhverjir innan hópsins hefðu látist á rannsóknartímabilinu.

Til að kanna félagslegar aðstæður var fundinn samanburðarhópur í gögnum Hagstofu Íslands. Stuðst var við gagnagrunnana „Mannfjöldi eftir kyni, aldri og hjúskaparstétt 1998-2008“, ${ }^{14}$ „Atvinnupátttaka, atvinnuleysi, vinnutími og fjöldi starfandi - árstölur 1991-2007“15 og „Fjöldi bótapega og bótagreiðslur vegna félagslegrar aðstoðar 1994-2007“.16 Tölfræðileg greining var gerð með forritinu SPSS 12.0 (SPSS Inc.233 South Wacker Drive, 11th Floor Chicago, IL 60606-6412). Niðurstöður eru sýndar sem meðaltöl og staðalfrávik $( \pm)$, eða miðgildi og hæsta og lægsta gildi par sem við á. Tölfræðileg marktækni var könnuð með Fischer exact test og miðað við p-gildi $<0,05$. Aðhvarfsgreining (Cox proportional hazard regression) var notuð til að finna hvaða breytur höfðu forspárgildi varðandi lifun. Var einstaklingum fylgt eftir frá fyrstu komu á gjörgæsludeild til 1. janúar 2007.

\section{Niðurstöður}

\section{Sjúklingahópurinn}

Á árunum 2000-2004 var 251 innlögn 224 einstaklinga vegna sjálfsvígstilrauna á gjörgæsludeildir Landspítala. Petta voru 4\% heildarfjölda innlagna eða 6\% (185) innlagna í Fossvogi og 2\% (66) innlagna á Hringbraut. Meðalfjöldi innlagna á ári vegna sjálfsvígstilrauna er pví $50 \pm 10$. Konur voru í meirihluta eða 61\% (152), en karlmenn 39\% (99). Tíu prósent (22) sjúklinganna voru lagðir inn oftar en einu sinni á tímabilinu (2-4 innlagnir) vegna endurtekinnar sjálfsvígstilraunar. Níu prósent (12) kvennanna stóðu fyrir 25 komum og 11\% (10) karlanna stóðu fyrir 23 komum. Meðalaldur hópsins var 36 ár \pm 14 og var hann svipaður milli kynja, 37 ár (13-79) fyrir konur en 36 ár (13-73) fyrir karla $(\mathrm{p}=0,46)$. Meðaltal APACHE II stigunar var 11,4 \pm 7 fyrir hópinn. Stór hluti eða $61 \%$ höfðu áður reynt sjálfsvíg, 63\% kvenna og $57 \%$ karla.

Til samanburðar voru á rannsóknartímanum lagðir inn að meðaltali $1213 \pm 125$ sjúklingar á gjörgæsludeildir Landspítala á ári, $609 \pm$ 38 á Hringbraut og $604 \pm 57$ í Fossvogi. Öndunarvélarmeðferð purftu $46 \%$ sjúklinga, meðaldur var $56 \pm 22$ ár, karlar $56 \%$ og konur 44\% og dánarhlutfall 9,1\%. Meðaltal APACHE II stigunar á gjörgæsludeild í Fossvogi var 11,8 8 .

\section{Tegund sjálfsáverka}

Sjálfsvígstilraun var oftast gerð með inntöku lyfja eða í 91\% (227) tilfella. Voru bensódíazepín algengustu lyfin (47\%), fylgt á eftir með príhringlaga geðdeyfðarlyfjum (tafla I). Meirihluti sjúklinga eða 67\% (151) notuðu fleiri en eitt lyf. Aðrar aðferðir voru notaðar í 9\% (23) tilfella, svo sem henging, kolmonóxíðeitrun, fall, drukknun, eggvopn og kemísk efni. Konur tóku lyf í 96\% tilfella (145) samanborið við 83\% karla (82). Karlar völdu oftar beinskeyttari aðferðir eða í 17\% (17) tilfella en konur $4 \%(6)(p=0,001)$. Að frátöldum lyfjaeitrunum var henging algengasta aðferðin eða í 3\% (7) tilfella. Meirihluti einstaklinga eða 56\% (141) var undir áhrifum áfengis pegar sjálfsvígstilraunin var framkvæmd.

\section{Meðferð á bráðamóttöku}

Hjá 29\% (72) sjúklinga reyndist koma á bráðamóttöku vera innan einnar klukkustundar frá inntöku lyfja, hjá 44\% (110) eftir lengri tíma en eina klukkustund frá inntöku en í 27\% (69) tilfella var tími frá inntöku ekki pekktur. Magaskolun ásamt gjöf lyfjakola var framkvæmd í tæplega helmingi tilfella í hverjum pessara priggja hópa, 1 46\% (33) tilfella peirra sem komu innan einnar klukkustundar frá inntöku, í 47\% (52) tilfella peirra sem komu seinna en einni klukkustund eftir inntöku og 1́ 39\% (27) tilfella peirra par sem tími frá inntöku var ópekktur.

Barkapræðing var framkvæmd við komu hjá 23\% (57) sjúklinga. Af peim sem komu innan einnar klukkustundar frá inntöku lyfja voru $26 \%$ (19) sjúklinga barkapræddir en af peim sem komu seinna en einni klukkustund eftir inntöku voru 21\% (23) barkapræddir og af peim sem höfðu ópekktan tíma frá inntöku lyfja voru 22\% (15) barkapræddir við komu.

\section{Gjörgæslumeðferð}

Á gjörgæsludeild voru allir sjúklingar vaktaðir á hefðbundinn hátt með hjartarafsjá, súrefnismettunarmæli og tíðum blóðprýstingsmælingum. Frekari vöktun með stöðugri blóðprýstingsmælingu og töku blóðgasa gegnum slagæðanál fengu 50\% sjúklinga (126), 6\% sjúklinga (16) fengu miðbláæðarlegg og 3\% (5) lungnaslagæðarlegg.

Eftir komu á gjörgæsludeild voru til viðbótar 5\% sjúklinga (13) barkapræddir. Alls purftu 67 sjúklingar eða $27 \%$ meðferð í öndunarvél en 1\% (3) sjúklinga önduðu nægjanlega sjálfir eftir barkapræðingu og purftu ekki stuðning af öndunarvél. Miðgildi á tíma í öndunarvél var 13 klst (1 klst-32 dagar) en meðaltími í öndunarvél var $56 \pm 122$ klst. Miðgildi gjörgæsludvalar var 19 
klst (2 klst-35 dagar) en meðaltal gjörgæsludvalar $41 \pm 81$ klst.

Lungnabólga var algengasti fylgikvillinn meðan á gjörgæslumeðferð stóð eða hjá 16\% (41) sjúklinga. Brátt andnauðarheilkenni (acute respiratory distress syndrome) fengu $2 \%$ (4) sjúklinga og 3\% (7) sjúklinga purftu blóðskilun, par af $2 \%$ (5) vegna lyfjaeitrunarinnar en $1 \%$ (2) vegna nýrnabilunar.

Eitt prósent (3) sjúklinga hlutu viðvarandi heilaskaða og $1 \frac{2}{2} \%$ (1) sjúklinga purfti lifrarígræðslu. Hjá 2\% (5) sjúklinga var gerð magaskolun og gefin lyfjakol á gjörgæsludeild en hjá 17\% (43) sjúklinga var haldið áfram með gjöf lyfjakola sem byrjað var með á bráðamóttöku. Önnur veitt meðferð var natríumbíkarbónat dreypi (13\%), naloxón/ flumasenil (9\%), acetylcystein dreypi (10\%), sýklalyf (24\%) og hjarta- og æðavirk lyf (13\%) en $27 \%$ (67) purftu aðeins venjubundna vöktun.

\section{Afdrif sjúklinga eftir útskrift af gjörgæeslu}

Meirihluti sjúklinga eða $54 \%$ (134) voru lagðir inn á lyflækningadeildir eftir útskrift af gjörgæsludeildum, $17 \%$ (43) fóru beint til innlagnar á geðdeild en 11\% (28) fóru beint heim eftir viðtal við geðlækni (tafla II) og var peim flestum fylgt eftir á göngudeild geðdeildar. Eftir útskrift af almennum legudeildum spítalans voru 19\% (46) sjúklinga lagðir inn á geðdeild. Af heildarhópnum voru pví 36\% (88) sjúklinga lagðir inn á geðdeild en 34\% (84) var fylgt eftir á göngudeild eða á einkastofu geðlæknis (tafla III). Ekki liggja fyrir allar upplýsingar um lengd eða eðli eftirfylgdarinnar. Geðlæknar slepptu hendi af alls $12(5 \%)$ sjúklingum par sem viðkomandi hafnaði frekara eftirliti og geðlæknir taldi ekki pörf á meðferð. Alls hlutu pví um $80 \%$ eftirfylgd innan geðheilbrigðiskerfisins.

\section{Geðgreiningar}

Algengasta aðalgeðgreining sjúklinga var fíkn eða hjá 43\% (108) hópsins. Næst kom punglyndis- og kvíðaraskanir hjá 23\% (tafla IV). Eingöngu er talin upp aðalgeðgreining en flestir sjúklingar höfðu tvær til fjórar geðgreiningar. Séu geðgreiningar lagðar saman og skoðaðar fyrir hvern einstakling breytist myndin talsvert. Algengust er pá greining punglyndis- og kvíðaraskana í 66\% tilfella, fíkn í $64 \%$ tilfella, persónuleikaraskanir 32\%, geðklofi eða geðklofalík einkenni 10\%, svörun við streitu og aðlögunarraskanir 9\%, geðhvörf 7\%, flogaveiki eða flog 7\% og átraskanir 5\%.

\section{Félagslegar aðstæður}

Pegar félagslegar aðstæður peirra sem reyna alvarlegar sjálfsvígstilraunir eru bornar saman við almennt pýði samkvæmt tölum frá Hagstofu sést að talsvert færri karlar eru í hjónabandi eða sambúð, stór hluti peirra fráskilinn og mun fleiri eru einhleypir (tafla V). Heldur fleiri konur en karlar eru í sambúð en stór hluti fráskildar eða einstæðar. Pegar atvinnupátttaka hópsins er könnuð sést að talsvert færri eru starfandi, mun fleiri á bótum og atvinnuleysi er mun algengara en hjá almennu pýði (tafla VI).

\section{Lifun}

Af 224 sjúklingum létust 7 meðan á sjúkrahúsdvöl stóð eða 3\%. Fimm peirra (2\%) létust á gjörgæsludeild og tveir(1\%)ályflækningadeildum. Eftir útskrift af spítala var 216 (99\%) fylgt eftir að meðaltali í 4,1 ár (31 dagur-7 ár) en ekki var vitað um afdrif eins útlendings. Á peim tíma lést 21 sjúklingur (10\%), 10 karlar og 11 konur. Níu létust á fyrsta ári, 5 á öðru og 6 á priðja ári frá dvöl á gjörgæsludeild. Aðeins einn sjúklingur lést eftir pað, kona á sjötta ári eftirfylgdar.

Í sjúkraskrám kom fram að hjá peim 21 sem lést á tímabilinu féllu 17 fyrir eigin hendi, hjá tveim var erfitt að ráða hvort andlát hefði orðið vegna slysfara eða sjálfsvígs og tveir virtust andast af náttúrulegum orsökum.

\section{Pattir með forspárgildi}

Í aðhvarfsgreiningu par sem tekið var tillit til aldurs, kyns og eftirskoðunartíma spáði fjöldi inntekinna taflna (meðaltal 109 miðgildi 88, bil 3-690), OR = 1,004 95\% CI 1,000-1,008 ( $\mathrm{p}=0,029)$, APACHE II gildið (miðgildi 12, meðalgildi 19, spönn 0-35), OR = 1,070 95\% CI 1,002-1,142 $(\mathrm{p}=0,045)$ og fjöldi almennra sjúkdómsgreininga (annarra en geðgreininga), $\mathrm{OR}=1,22$ 95\% CI 1,0071,481 ( $\mathrm{p}=0,042$ ) (meðalgildi 1,4; meðgildi 1,0; spönn 0-12) fyrir um áhættu á dauða eftir fyrstu komu á gjörgæslu.

Kyn, aldur, meðvitund við komu, pörf á öndunarvélarmeðferð, tími frá tilraun, félagsstaða, fyrri fjöldi sjálfsvígstilrauna og aðalgeðgreining voru pættir sem einnig voru rannsakaðir en enginn pessara pátta hafði marktækt forspárgildi. Рó að aðalgeðgreining hefði ekki forspárgildi fyrir lifun sýndi pað sig að einstaklingar með geðklofa og geðhvörf höfðu hæst dánarhlutfall á eftirskoðunartíma (23\% af geðklofahópi og 18\% úr geðhvarfahópi dóu á eftirskoðunartímabili). Hins vegar höfðu einstaklingar með punglyndis- og kvíðaraskanir lægri dánarlíkur (2\%).

\section{Umræða}

Samkvæmt niðurstöðum rannsóknarinnar eru 4\% allra innlagna á gjörgæsludeildir Landspítala 
Tafla I. Algengustu lyfin notuð við lyfjaeitrun, oft notuð lyf úr fleiri en einum lyfjaflokki ( $n=227$ komur). *

\begin{tabular}{lc}
\hline Lyfjaflokkur & Hlutfall (fjöldi) \\
\hline Bensódíazepín & $47 \%(106)$ \\
\hline Príhringlaga geðdeyfðarlyf & $26 \%(59)$ \\
\hline SSRI/SNRI & $21 \%(47)$ \\
\hline Hefðbundin geðrofslyf & $17 \%(38)$ \\
\hline Parasetamol og skyld lyf & $17 \%(38)$ \\
\hline Antihistamín & $16 \%(36)$ \\
\hline Óhefðbundin geðrofslyf & $14 \%(32)$ \\
\hline * Önnur aðferð en lyf notuð i 23 tilfellum, ófullnægjandi upplýsingar í einu tilfelli.
\end{tabular}

Tafla II Afdrif sjúklinga eftir útskrift af gjörgæslu (n=246). *

\begin{tabular}{lc}
\hline Afdrif & Hlutfall (fjöldi) \\
\hline Innlögn á lyflækningadeild & $54 \%(134)$ \\
\hline Innlögn á geðdeild & $17 \%(43)$ \\
\hline Útskrift heim & $11 \%(28)$ \\
\hline Innlögn á barnadeild & $7 \%(16)$ \\
\hline Innlögn á barna- og unglingageðdeild & $<1 \%(1)$ \\
\hline Innlögn á skurðdeild & $1 \%(3)$ \\
\hline Útskrift gegn vilja læknis & $<1 \%(1)$ \\
\hline Upplýsingar vantar i sjúkraskrá & $8 \%(20)$
\end{tabular}

* Fimm sjúklingar létust á gjörgæslu.

Tafla III. Eftirfylgd sjúklinga eftir útskrift af gjörgæslu og almennum deildum ( $n=244)$ *

\begin{tabular}{lc}
\hline Tegund eftirfylgdar & Hlutfall (fjöldi) \\
\hline Innlögn á geðdeild & $36 \%(88)$ \\
\hline Göngudeild & $24 \%(59)$ \\
\hline Einkastofa geðlæknis & $10 \%(25)$ \\
\hline Eftirfylgd talin ópörf** & $5 \%(12)$ \\
\hline Innlögn á barna- og unglingageðdeild & $4 \%(9)$ \\
\hline Áfengismeðferð & $3 \%(8)$ \\
\hline Heimilislæknir & $2 \%(4)$ \\
\hline Sálfræðingur & $2 \%(4)$ \\
\hline Engin eftirfylgd & $1 \%(2)$ \\
\hline Annað & $1 \%(2)$ \\
\hline Upplýsingar vantar i sjúkraskrá & $13 \%(31)$ \\
\hline
\end{tabular}

*Alls létust 7 sjúklingar á sjúkrahúsi (5 á gjörgæslu og 2 á almennum deildum).

** Sjúklingur hafnaði eftirfylgd og geðlæknir taldi hana óparfa.

vegna sjálfsvígstilrauna. Dánartíðni pessa hóps á sjúkrahúsi er umtalsverð (3\%) miðað við meðalaldur hans. Sjálfsvígstíðni er há innan hópsins á næstu árum eftir útskrift af sjúkrahúsi (10\%) pó svo að meirihluti hans $(80 \%)$ hljóti eftirfylgd innan geðheilbrigðiskerfisins.

\section{Sjúklingahópurinn}

Að meðaltali leggjast 50 einstaklingar á ári inn á gjörgæsludeildir Landspítala vegna alvarlegrar sjálfsvígstilraunar. Sjúklingahópurinn er tiltölu- lega ungur (36 ár \pm 14 ) og konur eru í meirihluta (61\%) sem er andstætt pví sem gerist almennt á gjörgæsludeildum. ${ }^{17}$ Petta er í samræmi við nýlega rannsókn á alvarlegum sjálfsvígum í Finnlandi par sem litið var á alla pá sem purftu á sjúkrahúsvist að halda eftir sjálfvígstilraun. ${ }^{1}$

Mjög hátt hlutfall hópsins (61\%) hafði áður gert sjálfsvígstilraun og var pað nánast jafnt meðal karla og kvenna sem bendir til pess að pessi hópur sé frábrugðinn hinum almenna hópi sem kemur á bráðamóttöku vegna sjálfsskaða.8, 10 Í áðurnefndri rannsókn hafði 21\% hópsins sögu um fyrri tilraun en petta gæti skýrst á mismunandi inntökuskilyrðum í rannsóknunum. ${ }^{1}$ Í finnsku rannsókninni voru kannaðar allar innlagðar sjálfsvígstilraunir en í pessari rannsókn einungis sá hópur sjálfsvígstilrauna sem purfti meðferð á gjörgæsludeild og ætla má að hópurinn í pessari rannsókn hafi pví gert alvarlegri og ákveðnari tilraun.

Af hópnum lögðust 10\% aftur inn á gjörgæsludeild á rannsóknartímabilinu vegna endurtekinnar tilraunar. Samrýmist pað niðurstöðum annarra rannsókna en talið er að peir sem reynt hafa sjálfsvíg séu í áhættu að sýna áfram sjálfsvígshegðun (12-30\%) og sú áhætta sé aukin sérstaklega á fyrsta ári eftir sjálfsvígstilraun. ${ }^{1,8,18}$

\section{Tegund sjálfsáverka}

Inntaka lyfja var algengasta aðferðin við sjálfsvígstilraunina (91\%). Pau lyf sem mest voru notuð reyndust bensódíazepín, príhringlaga geðdeyfðarlyf og síðan nýrri punglyndislyf sem er í samræmi við aðrar rannsóknir. ${ }^{1,19-21}$ Byggist petta val væntanlega á aðgengi lyfja í umhverfi sjúklingsins. Líklegast hafa pau lyf verið notuð sem læknir hefur skrifað upp á vegna meðferðar enda $61 \%$ með sögu um fyrri sjálfsvígstilraun og væntanlega verið til meðhöndlunar hjá læknum. Раð er pví óhægt um vik að fjarlægja pennan orsakavald úr umhverfinu. Draga má pó úr honum með pví að taka upp lyfjaskömmtun eða ávísa sem lægstum skammti hverju sinni. Petta ber að íhuga í hverju tilviki eftir sjálfsvígstilraun.

Karlar notuðu oftar beinskeyttari og alvarlegri aðferðir sem einnig er pekkt annars staðar frá. ${ }^{3}$ Petta er einnig í samræmi við að karlar á Íslandi nota oftar skotvopn en konur lyf í staðfestum sjálfsvígum. ${ }^{4}$ Ríflega helmingur sjúklinganna (56\%) var undir áhrifum áfengis pegar sjálfsvígstilraunin var gerð en áfengisvíma er pekktur áhættupáttur fyrir bæði sjálfsvígstilraunir og sjálfsvíg. ${ }^{22}$

\section{Meðferð á bráðamóttöku}

Раð vekur athygli hve stór hluti sjúklinga fær magaskolun prátt fyrir að hafa tekið lyfin inn 
meira en einni klukkustund fyrir komu eða ekki sé vitað um hvenær peir tóku lyfin. Leiðbeiningar síðustu ár hafa bent á takmarkaða gagnsemi magaskolunar, lítinn klínískan árangur ${ }^{23,}{ }^{24}$ og engan mun á dánartíðni. ${ }^{25}$ Jafnvel hefur verið sýnt fram á auknar líkur á ásvelgingu og innlögnum á gjörgæsludeild. ${ }^{26}$

\section{Meðferð á gjörgæesludeild}

Um priðjungur sjúklinga purfti einungis hefðbundna vöktun og hefði hugsanlega mátt vakta annars staðar en á gjörgæsludeild. Annar priðjungur purfti meðferð í öndunarvél og var pað í flestum tilfellum vegna skertrar meðvitundar og öndunar vegna inntöku lyfja. Er pað í samræmi við stuttan miðgildistíma í öndunarvél (13 klst) og veru á gjörgæsludeild (19 klst). Ásvelging vegna skertrar meðvitundar skýrir sennilega algengi lungnabólgu (16\%). Um 5\% sjúklinganna hlaut mjög alvarlegar aukaverkanir af völdum eitrunarinnar og purftu flókna gjörgæslumeðferð. Stærsti hluti sjúklinga eftir sjálfsvígstilraun fer pví í gegnum gjörgæsludvöl án verulegra eftirkasta.

\section{Afdrif sjúklinga eftir gjörgæsludvöl}

Ávallt er leitað samráðs við geðlækna áður en sjúklingur sem gert hefur sjálfsvígstilraun útskrifast af gjörgæsludeild en mat geðlæknis fer pó stundum fram eftir að sjúklingar hafa verið fluttir á almenna legudeild. Um 80\% sjúklinganna útskrifuðust á aðrar deildir sjúkrahússins af gjörgæsludeild en 11\% útskrifuðust heim og pá alltaf í samráði við geðlækna (tafla II). Eftir að líkamlegum bata var náð eftir tilraunina hlaut ríflega priðjungur meðferð inni á geðdeildum Landspítala og fjórðungi var fylgt eftir á göngudeild geðdeildar sjúkrahússins. Í 10\% tilvika var eftirfylgni á einkastofum geðlækna en öðrum úrræðum beitt í 11\% tilvika (tafla III). Um $80 \%$ sjúklinganna bauðst pví einhvers konar eftirfylgni innan geðheilbrigðiskerfisins. Gögn rannsóknarinnar gáfu ekki upplýsingar um hvernig pessari meðferð var háttað, gæði hennar, lengd eða meðferðarúrræði.

Раð er pekkt að peir sem reynt hafa sjálfsvíg hafi jafnan efasemdir um eftirmeðferð og sinni henni illa. ${ }^{20,27}$ Ástæða væri pví til að skoða betur í framtíðinni skipulag eftirfylgdar pessara sjúklinga og hversu vel pörfum peirra er mætt.

\section{Geðgreiningar}

Nær allir sjúklingarnir (99\%) höfðu geðgreiningu, flestir fleiri en eina. Geðlagsraskanir og fíkn voru algengastar í hópnum. Vitað er að allir geðsjúkdómar hafa sterka tengingu við sjálfsvíg og sjálfsvígstilraunir. ${ }^{1,4, ~ 8, ~ 22, ~ 28, ~} 29$ Skoða parf betur í
Tafla IV. Aðalgeðgreiningar sjúklinga $(n=249)^{\star}$ miðað við komur.

\begin{tabular}{lc}
\hline Aðalgeðgreining & Hlutfall (fjöldi) \\
\hline Fíkn & $43,4 \%(108)$ \\
\hline Punglyndi og kvíðaraskanir & $23,3 \%(58)$ \\
\hline Stress og aðlögunarraskanir & $8,8 \%(22)$ \\
\hline Geðklofi & $8,0 \%(20)$ \\
\hline Geðhvörf & $7,2 \%(18)$ \\
\hline Persónuleikaröskun & $4,8 \%(12)$ \\
\hline Átröskun & $1,6 \%(4)$ \\
\hline Flogaveiki & $1,6 \%(4)$ \\
\hline Vefrænir skaðar & $0,8 \%(2)$ \\
\hline Enginn örugg geðgreining & $0,4 \%(1)$ \\
\hline *Vantaði fullnægjandi upplýsingar um tvo einstaklinga til að gera geðgreiningu.
\end{tabular}

Tafla V. Hjúskaparstaða sjúklinga samanborið við pjóðfélagshóp á sama aldursbili (1667ára). ${ }^{14}$

\begin{tabular}{lccc}
\hline \multicolumn{1}{c}{ Hjúskaparstétt } & Kyn & Sjúklingahópur & Almennt pýði \\
\hline Giftir & Karlar & $26 \%$ & $48 \%$ \\
\cline { 2 - 4 } & Konur & $27 \%$ & $54 \%$ \\
\hline Í sambúð & Karlar & $10 \%$ & $18 \%$ \\
\cline { 2 - 4 } & Konur & $25 \%$ & $17 \%$ \\
\hline Skilin að lögum & Karlar & $19 \%$ & $5 \%$ \\
\cline { 2 - 4 } & Konur & $25 \%$ & $7 \%$ \\
\hline Einhleypir & Karlar & $44 \%$ & $24 \%$ \\
\cline { 2 - 4 } & Konur & $23 \%$ & $18 \%$ \\
\hline
\end{tabular}

Tafla VI. Atvinnupátttaka og bótapega sjúklinga samanborið við pjóðfélagshóp á sama aldursbili (16-74 ára). ${ }^{15,16}$

\begin{tabular}{lcc} 
& Sjúklingahópur & Almennt pýði \\
\hline Starfandi & $37 \%$ & $83 \%$ \\
\hline Á bótum & $41 \%$ & $6 \%$ \\
\hline Atvinnulaus & $12 \%$ & $3,0 \%$
\end{tabular}

framtíðinni nákvæmni geðgreininga (aðal- og aukagreiningar) og hvort einstaklingar hafi hlotið viðeigandi meðferð í samræmi við geðgreiningu.

\section{Félagslegar aðstæður}

Í pessari rannsókn kom sterkt fram að sjúklingahópurinn aðskildi sig verulega frá almennu pýði. Mun fleiri voru einhleypir, bæði meðal karla og kvenna (tafla V), mun færri voru á almennum vinnumarkaði og fleiri atvinnulausir eða á bótum (tafla VI).

Petta er í samræmi við niðurstöður annarra rannsókna sem hafa í gegnum tíðina sýnt að sjálfsvígstilraunir tengjast félagslegum páttum, til dæmis lágum tekjum, atvinnuleysi, skorti á menntun og einstæðingsskap. 3, 8, 21, 27, 29, 30

\section{Lifun}

Dánarhlutfall sjúklingahópsins meðan á sjúkrahúsdvöl stóð var 3\% sem er hátt fyrir pennan 
aldurshóp en er pó lægra en niðurstöður annarra rannsókna á afleiðingum sjálfsvígstilrauna gefa til kynna ${ }^{31,32}$ en par hefur dánartíðni verið allt að $34 \% .{ }^{33}$ Pessi munur getur pó stafað af mismunandi samsetningu sjúklingahópa. Dánarhlutfall sjúklinga eftir fyrstu sjálfvígstilraun sem leiðir til innlagnar á gjörgæsludeild helst hátt fyrstu prjú árin eftir útskrift af spítala (10\%), svipað og sýnt hefur verið í öðrum rannsóknum. ${ }^{10,18,34,35}$ Hættan er mest fyrsta árið eftir tilraunina líkt og aðrar rannsóknir hafa sýnt. ${ }^{10,18,28,34}$ Andlátin urðu flest vegna sjálfsvíga. Petta dánarhlutfall hlýtur að valda vonbrigðum.

Раð er pekkt að ekki er einungis aukin hætta á sjálfsvígum eftir fyrri sjálfvígstilraunir, heldur eru einnig auknar líkur á andláti af völdum annarra sjúkdóma og slysa. ${ }^{10,18,28,34}$ Dánarorsök gjörgæsluhópsins sem fylgt var eftir var í 80\% tilfella sjálfsvíg. Sjúklingahópurinn sem lendir á gjörgæsludeild virðist pví vera enn líklegri til að deyja af völdum sjálfsskaða en aðrir sjúklingar sem gera sjálfsvígstilraun (til dæmis peir sem fara einungis á bráðamóttöku eða beint á almennar legudeildir). Styrkir petta grun um að pessi hópur hafi haft sterkan ásetning að deyja. Mjög erfitt hefur pó reynst að greina í sundur í eftirfylgdarrannsóknum einstaklinga sem lenda síðar í sjálfsvígshóp frá peim sem einungis gera alvarlegar tilraunir. ${ }^{30}$

Lifun eftir sjálfsvígstilraun í rannsóknarhópnum var sambærileg á milli kynja sem er frábrugðið niðurstöðum fyrri rannsókna á sjálfsvígsáhættu eftir sjálfsvígstilraun. Yfirleitt hafa karlar miklu meiri sjálfsvígsáhættu í framtíðinni eftir sjálfsvígstilraun samanborið við konur. ${ }^{10,}{ }^{18,}$ ${ }^{28,34}$ Konur eru yfirleitt mun fjölmennari í öllum sjálfsvígstilraunahópum og yngri konur gera oftar vægari tilraunir. ${ }^{3,8,10}$ Konur í okkar hópi sem komu á gjörgæsludeild voru eldri en karlarnir og einnig eldri en í sambærilegum rannsóknum. Vitað er að sjálfsvígsáhætta kvenna eykst pví eldri sem pær eru pegar pær gera sjálfsvígstilraun. ${ }^{10,28,34}$

\section{Pættir með forspárgildi}

Fjöldi inntekinna taflna, hærra APACHE II skor og fjöldi líkamlegra sjúkdómsgreininga juku marktækt áhættu á síðari sjálfsvígstilraun. Aukinn fjöldi inntekinna taflna og hærra APACHE skor vegna lélegs líkamlegs ástands framkallað af sjálfsvígstilraun má túlka sem meiri ákveðni í vilja til að deyja. ${ }^{35}$ Meiri fjöldi sjúkdómsgreininga getur endurspeglað bágborið heilsufar en pekkt er að lélegt heilsufar er áhættupáttur fyrir sjálfsvígum eftir sjálfsvígstilraun. . $2,29,35^{2}$

Fyrri sjálfsvígstilraun var mjög algeng (61\%) í hópnum en fjöldi fyrri tilrauna spáði pó ekki fyrir um dánarlíkur í pessari rannsókn, hugsanlega var hópurinn of einsleitur að pessu leyti til að fá fram marktækni.

Pó að aðalgeðgreining hefði ekki forspárgildi fyrir lifun sýndi sig að einstaklingar með geðrof (geðklofasjúkdóm) og geðhvörf höfðu hæst dánarhlutfall, 23\% dóu af geðrofshópi og 18\% úr geðhvarfahópi á eftirskoðunartímabili. Pessi niðurstaða er í samræmi við aðrar rannsóknir sem sýna að geðrofs- og geðhvarfasjúklingar eru í meiri sjálfsvígshættu eftir tilraun miðað við aðrar geðgreiningar. ${ }^{1,28,30}$ Punglyndis- og kvíðaraskanir höfðu einungis $2 \%$ dánarlíkur en erfitt er að greina sundur kvíða- og punglyndisraskanir. Í pessari rannsókn var punglyndum sem sannað var að hefðu geðhvörf skipað í geðhvarfahóp. Í rannsóknum eru punglyndis- og kvíðasjúkdómar oft sameinaðir í einn flokk en í nýlegri grein ${ }^{30}$ sem skoðaði alvarlegar sjálfsvígstilraunir og sjálfsvíg sem tókust sýndi sig að punglyndir voru í báđum hópunum en kvíðnir voru marktækt oftar áfram í sjálfsvígstilraunahópi. Er pað í samræmi við okkar niðurstöðu. Fíkniraskanir hafa sterka skörun við allar geðraskanir, sérstaklega lyndisraskanir, og valda erfiðleikum við mat á áhrifum geðraskana en fíkn var algengasta aðalgeðgreiningin í pessari rannsókn eða í $43 \%$ tilfella. Auk pess var meirihluti eða $56 \%$ undir áhrifum áfengis pegar tilraunin var gerð en áfengisvíma hefur bein áhrif til neikvæðra tilfinninga, sjálfsvígshugsana eða slíkt getur komið fram í fráhvarfsfasa. ${ }^{22,28}$

\section{Ályktun}

Árlega leggjast inn um 50 einstaklingar á gjörgæsludeildir Landspítala vegna alvarlegra sjálfsvígstilrauna par sem inntaka lyfja er algengasta orsökin (91\%). Petta er ungur sjúklingahópur, konur eru í meirihluta og tíðni á fíkni-, kvíða- og punglyndisröskunum er há. Félagslega stendur pessi hópur verr en samanburðarhópur úr almennu pýði með hátt hlutfall öryrkja, atvinnulausra og einstæðinga. Dánartíoni á sjúkrahúsi er 3\% sem telst há fyrir pennan aldurshóp og hún helst há eftir útskrift af sjúkrahúsi $(10 \%)$ prátt fyrir að hátt hlutfall hópsins $(80 \%)$ fái eftirfylgni innan geðheilbrigðiskerfisins. Раð vekur spurningar um hvort meðferðarúrræði sem í boði eru séu nægjanlega árangursrík.

\section{Pakkir}

Vísindasjóður Landspítala fær pakkir fyrir veittan styrk við framkvæmd rannsóknarinnar. 


\section{Heimildir}

1. Haukka J, Suominen K, Partonen T, Lonnqvist J. Determinants and outcomes of serious attempted suicide: a nationwide study in Finland, 1996-2003. Am J Epidemiol 2008; 167: 115563 .

2. Hagstofa Íslands: www.hagstofan.is/. Sótt nóvember 2008.

3. Hawton K, Catalan J. Självmordförsök. Bedömning och behandling, vol. 2. Bokförlaget Natur och Kultur, Lund 1985.

4. Jónsdóttir G. Sjálfsmorð á Íslandi. Læknablaðið 1977; 63: 4763.

5. Sigurðsson P, Jónsdóttir G. Sjálfsvíg á Norðurlöndum 1880-1980. Samanburður milli landa og hugsanlegar skráningarskekkjur. Læknablaðið 1985; 71: 86-90.

6. Tómasson $K$, Zöega T. Sjálfsvíg og önnur voveifleg mannslát á Íslandi 1951-1990. Læknablaðið 1993; 79: 71-6.

7. Hawton $\mathrm{K}$, van Heeringen $\mathrm{K}$. The International Handbook of Suicide and Attempted Suicide, vol. 33. John Wiley \& Sons, West Sussex 2000

8. Pálsson SP, Jónsdóttir G, Pétursson H. Parasuicidal behaviour in an emergency room population. Nord Psykiatr Tidskr 1991; 45: 351-6.

9. Hawton $\mathrm{K}$, van Heeringen $\mathrm{K}$. The International Handbook of Suicide and Attempted Suicide, vol. 31. John Wiley \& Sons, West Sussex 2000.

10. Pálssson SP, Jónsdóttir G, Pétursson H. The mortality risk of a psychiatric emergency patients. A follow - up study. Nord J Psychiatry 1996; 50: 207-16.

11. Kristinsson J, Pálsson R, Guðjónsdóttir GA, Blöndal M, Guðmundsson S, Snook CP. Acute poisonings in Iceland: a prospective nationwide study. Clin Toxicol (Phila) 2008; 46: 126-32.

12. Silverman MM. The language of suicidology. Suicide Life Threat Behav 2006; 36: 519-32.

13. Knaus WA, Draper EA, Wagner DP, Zimmerman JE APACHE II: a severity of disease classification system. Crit Care Med 1985; 13: 818-29.

14. Hagstofa Íslands: www.hagstofa.is Sótt nóvember 2008.

15. Hagstofa Íslands: www.hagstofa.is Sótt nóvember 2008.

16. Hagstofa Íslands: www.hagstofa.is Sótt nóvember 2008.

17. Karason S, Antonsen $K$, Aneman A. Ventilator treatment in the Nordic countries. A multicenter survey. Acta Anaesthesiol Scand 2002; 46: 1053-61.

18. Sigurjónsdóttir JM, Briem N, Jónsdóttir G, Pálsson SP, Pétursson $\mathrm{H}$. Tíðni sjálfsvíga hjá peim sem áđur hafa reynt sjálfsvíg. Læknablaðið 1993; 79: 335-41.

19. Doshi A, Boudreaux ED, Wang N, Pelletier AJ, Camargo CA, Jr. National study of US emergency department visits for attempted suicide and self-inflicted injury, 1997-2001. Ann Emerg Med 2005; 46: 369-75.

20. Nordentoft M, Sogaard M. Registration, psychiatric evaluation and adherence to psychiatric treatment after suicide attempt. Nord J Psychiatry 2005; 59: 213-6.
21. Palsson SP, Jonsdottir G, Petursson H: Emergency psychiatry in a general hospital. Nord Psykiatr Tidsskr 1990; 44: 345-52

22. Sher L, Oquendo MA, Richardson-Vejlgaard R, et al. Effect of acute alcohol use on the lethality of suicide attempts in patients with mood disorders. J Psychiatr Res 2009; 43: 901-

23. Minton NA, Glucksman E, Henry JA. Prevention of drug absorbtion in simulated theophylline overdose. Hum Exp Toxicol 1995; 14: 170.

24. Pond SM, Lewis-Driver DJ, Williams GM, Green AC, Stevenson NW. Gastric emptying in acute overdose: a prospective randomised controlled trial. Med J Aust 1995; 163: 345-9.

25. Kulig K, Bar-Or D, Cantrill SV, Rosen P, Rumack BH. Management of acutely poisoned patients without gastric emptying. Ann Emerg Med 1985; 14: 562-7.

26. Merigan KS, Woodard M, Hedges JR, Roberts JR, Stuebing R, Rashin MC. Prospective evaluation of gastric emptying in the self-poisoned patient. Am J Emerg Med 1990; 8: 479.

27. Cedereke M, Monti K, Ojehagen A. Telephone contact with patients in the year after a suicide attempt: does it affect treatment attendance and outcome? A randomised controlled study. Eur Psychiatry 2002; 17: 82-91.

28. Hawton K, Fagg J. Suicide, and other causes of death, following attempted suicide. Br J Psychiatry 1988; 152: 35966

29. Hawton K. Assessment of suicide risk. Br J Psychiatry 1987; 150: $145-53$

30. Beautrais AL. Suicides and serious suicide attempts: two populations or one? Psychol Med 2001; 31: 837-45.

31. Burillo-Putze G, Munne P, Duenas A, et al. National multicentre study of acute intoxication in emergency departments of Spain. Eur J Emerg Med 2003; 10: 101-4.

32. Viertel A, Weidmann E, Brodt HR. [Cases of acute poisoning admitted to a medical intensive care unit]. Dtsch Med Wochenschr 2001; 126: 1159-63. Pýska.

33. Gaillard M, Martel S, Reynaud P, Mercadal L, Liger C, Herve C. [Severe suicides: short- and long-term outcome. Assessment of their quality of life]. Agressologie 1990; 31: 749-52. Franska.

34. Nordstrom P, Samuelsson M, Asberg M. Survival analysis of suicide risk after attempted suicide. Acta Psychiatr Scand 1995; 91: 336-40.

35. Suominen K, Isometsa E, Ostamo A, Lonnqvist J. Level of suicidal intent predicts overall mortality and suicide after attempted suicide: a 12-year follow-up study. BMC Psychiatry 2004; 4: 11.

36. Hawton K, Harriss L, Zahl D. Deaths from all causes in a long-term follow-up study of 11,583 deliberate self-harm patients. Psychol Med 2006; 36: 397-405.

\section{Clinical aspects and follow up of suicide attempts treated in a general Intensive Care Unit at Landspitali University Hospital in Iceland 2000-2004.}

Objective: To gather information on patients admitted to an intensive care unit (ICU) after a serious suicide attempt $(\mathrm{SA})$.

Methods: Retrospective analysis and follow up of admittances to ICUs of Landspitali University Hospital after SA years 2000-2004.

Results: Admittances because of SA were 251 (4\% of ICU admissions, $61 \%$ females, 39\% males, mean age 36 $\mathrm{yr} \pm 14$ ). Ten percent were admitted more than once and $61 \%$ had prior history of SA. Drug intoxication was the most prevalent type of SA (91\%) and the most frequent complication was pneumonia. Following ICU stay 36\% of the patients were admitted to psychiatric wards and $80 \%$ received psychiatric follow up. The main psychiatric diagnosis was addiction (43\%). Majority of patients were divorced or single and the rate of unemployment was high. Mortality during ICU stay was 3\%. During 3-7 year follow up 21 patients died (10\%), majority due to suicide. In a survival analysis only the number of tablets taken, APACHE II score and number of somatic diseases predicted risk of death.

Conclusion: The patient group is young (36 yr), majority are women $(61 \%)$, repeated attempts are frequent, social circumstances are poor and death rate after discharge from hospital is high (10\%) even though the vast majority $(80 \%)$ receives psychiatric follow up.This raises the question if the offered treatment is effective enough.

Sverrisson KO, Palsson SP, Sigvaldason K, Karason S.

Clinical aspects and follow up of suicide attempts treated in a general Intensive Care Unit at Landspitali University Hospital in Iceland 2000-2004. Icel Med J 2010; 96: 101-7

Key words: Suicide attempt, suicide, drug poisoning, intensive care, mental health care.

Correspondence: Sigurbergur Kárason, skarason@landspitali.is

Barst: 3. september 2009, - sampykkt til birtingar: 6. janúar 2010 Hagsmunatengsl: Engin 